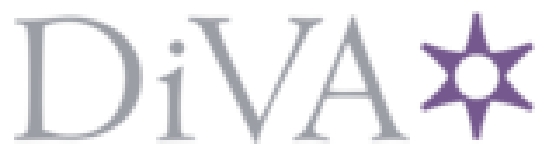

http://www.diva-portal.org

This is the published version of a paper published in European Physical Education Review.

Citation for the original published paper (version of record):

Janemalm, L., Quennerstedt, M. (2019)

What is complex in complex movement? A discourse analysis of conceptualizations of movement in the Swedish physical education curriculum

European Physical Education Review, 25(4): 1146-1160

https://doi.org/10.1177/1356336X18803977

Access to the published version may require subscription.

N.B. When citing this work, cite the original published paper.

Permanent link to this version:

http://urn.kb.se/resolve?urn=urn:nbn:se:oru:diva-77415 


\title{
What is complex in complex movement? A discourse analysis of conceptualizations of movement in the Swedish physical education curriculum
}

European Physical Education Review 2019, Vol. 25(4) II46-II60 (C) The Author(s) 2018 Article reuse guidelines: sagepub.com/journals-permissions DOI: $10.1177 / 1356336 \times 18803977$ journals.sagepub.com/home/epe

@SAGE

\author{
Lucas Janemalm \\ Örebro University, Sweden
}

\section{Mikael Quennerstedt}

Örebro University, Sweden

\section{Dean Barker}

University of Gothenburg, Sweden; The Swedish School of Sport and Health Sciences (GIH), Sweden

\begin{abstract}
In 201 I, the Swedish National Agency for Education introduced a new national curriculum. The curriculum contained a number of new terms. One in particular proved problematic for physical educators - complex movement. The confusion surrounding the term could be seen as somewhat unexpected since movement is and has been a central element of practically all physical education (PE) curricula. The specific aim of this paper is to identify how the discourse regarding complex movement is assembled, and by doing so, provide insights into the meaning(s) of complex movement within the context of PE policy in Sweden. Following Englund and Quennerstedt (2008), the study is framed within a Swedish curriculum theory tradition and six policy texts are examined using a discourse analytic methodology. The results suggest three different inferences of complex movement discourse: advanced with a wide meaning; context-dependent and related to sports for older pupils; and knowledge-dependent where different views about knowledge exist. From these results, three discussion points are raised related to: the diversity of possible meanings presented in policy; the connection between knowledge and understanding; and the probability of different audiences reading the texts in different ways. The paper is concluded with a consideration of the consequences of different inferences concerning complex movement and whether greater consensus is necessary.
\end{abstract}

\section{Corresponding author:}

Lucas Janemalm, School of Health and Medical Sciences, Örebro University, 70I 82 Örebro, Sweden.

Email: lucas.janemalm@oru.se 


\section{Keywords}

Complex movement, curriculum transformation, discourse analysis, physical education

\section{Introduction}

In 2011, the Swedish National Agency for Education (SNAE) introduced a new national curriculum for all grades. ${ }^{1}$ Its predecessor, the curriculum issued in 1994, had been criticised for being vague and unhelpful for practitioners, not least regarding assessment and grading (Lundvall and Meckbach, 2008; Seger, 2014; Tholin, 2006). Teachers and politicians expected that the 2011 syllabus' more prescriptive form would provide specific, practical guidance in the classroom. This expectation was only partially met. A number of educators were disappointed with a relatively 'slim' document that outlined a number of objectives but prescribed few strategies for achieving these objectives (Redelius et al., 2015). In the grading criteria for year seven to year nine, a new concept proved especially confounding: complex movement. While physical educators had always attempted to teach students how to move, they were now required to teach students to move in 'complex' ways as well as to give equivalent and comparable grades on this complexity (Redelius, et al., 2015; Svennberg et al., 2014). Specifically, students were - and still are - supposed to learn to 'participate in games and sports involving complex movement in different settings and vary and adapt their movements well to activities and context' (Skolverket, 2011). Since 2011, this addition has caused Swedish physical education (PE) teachers a great deal of anxiety (see, for example, Schenker, 2012) with questions of definition, implementation, and assessment in the foreground (Svennberg, 2017; Tolgfors and Öhman, 2016).

Researchers internationally have described how the creation of new policy has led to challenges in PE practice (e.g. Brown and Penney, 2013; Ha et al., 2008; Macdonald, 2013; Peiroó-Velert et al., 2015; Penney, 2008; Penney et al., 2009; Thorburn and Collins, 2006). In one sense, it is not surprising that an updated national curriculum has resulted in some confusion and ensuing debate. The introduction of a strengths-based approach to health in Australia, for example, led to substantial discussion (Macdonald, 2013; McCuaig et al., 2013). What is surprising however, is that the debate in Sweden has concerned ways of moving (Larsson and Nyberg, 2017). Moving has after all been a long-standing element of PE curricula internationally (Kirk, 2010), and has received a great deal of scholarly attention (see, for example, Stodden et al., 2008; Whitehead, 2001). Moving is one aspect of the school subject in which we might expect physical educators to feel confident. With these points in mind, the broad purpose of this investigation is to discern what the phrase 'complex movement' entails in the current Swedish national curriculum. Using a discourse analytic approach (Howarth, 2000; Jørgensen et al., 2002), the specific aim is to identify how the discourse regarding complex movement is assembled and by doing so, provide insights into the meaning(s) of complex movement within the context of PE policy in Sweden. This task, we believe, can facilitate a broader discussion about the ways in which physical educators conceptualise, employ, and as a consequence assess a key aspect of their practice. Our basic theoretical assumption is that all texts (e.g. words, phrases, and actions) acquire their meaning within the contexts in which they occur. This makes identifying the terms and phrases that surround the phrase 'complex movement' in the curriculum and other supporting documents, and 'reading between the lines' (Culler, 1992) to grasp the kinds of assumptions that remain implicit in the texts, a central part of the analytic task. 
The next section comprises an overview of PE literature that has a focus on what we would call movement education. In this review, we identify the ways that the idea of complexity has been connected to movement. We then outline our methodological approach, summarizing principles of discourse analytic thinking that proved useful in this investigation. Our results follow. Then, we present and discuss the data and point out key ideas that potentially structure how PE teachers make sense of complex movement. We finish by relating these ideas to the movement education literature, and considering some implications for practice.

\section{Background}

Movement and movement learning have garnered a great deal of attention from PE scholars (for overviews see Barker et al., 2017; Larsson and Quennerstedt, 2012). Different perspectives have been adopted including: phenomenological perspectives (Brown and Payne, 2009; Kentel and Dobson, 2007; Whitehead, 2001); developmental motor learning perspectives (Boyce et al., 2006; Stodden et al., 2008); non-linear pedagogic perspectives (Chow, 2013; Chow and Atencio, 2014); and constructivist perspectives (Light and Wallian, 2008). In this section we focus specifically on how PE scholars have used the term 'complex' in relation to movement in PE. Using a discursive approach (described in the next section), we identify four mutually supporting inferences that scholars have attached to the term and offer explanations and examples for each. These four inferences are: (i) complex as advanced; (ii) complex as context-dependent; (iii) complex as dynamic and changing; and (iv) complex as demanding reflective processing. We then briefly examine some of the wider assumptions that underpin these usages. A preliminary point to note is that complex movement is not a scientific concept for which one can find a definition or description. Nowhere did we find a statement saying 'a complex movement is one which....' In fact, some would suggest that a tight definition of complexity contradicts the sense of emergence and unpredictability that the term attempts to convey (Ovens et al., 2013). At the same time, 'complex' is used relatively frequently in the movement learning literature and there is some consensus, at least on the surface, around the ways that it can be employed.

A common connotation of complex is that the movement is advanced. 'Complex' is used in this sense to distinguish between 'fundamental' or 'basic' ways of moving that are typically learned in elementary (or primary) school and ways of moving that are superior, higher or more sophisticated, and that are done later in education (Delaš et al., 2008; Rukavina and Jeansonne, 2009). Complex here is connected to notions of progression and development (see Stodden et al., 2008) and is used to mean more 'mature' (Miller et al., 2007: 63). Alone, this connotation is not enough to tell us what complex movements might look like in practice, other than that they might be performed by 'older kids.' However, combined with the following aspects a more detailed picture begins to emerge.

Some scholars use 'complex' to signify that a way of moving belongs to a specific context (e.g. Chow et al., 2007). In contradistinction to general or fundamental ways of moving, complex movements are done in certain situations that place certain demands on the mover. A general overhand throwing movement, for example, might be done anywhere - or at least in a variety of different places and has thus been referred to as a fundamental movement (Drost and Todorovich, 2013). A javelin-throw, in contrast, with its specific grip and run up and the fact that it belongs to an athletics context, is complex. The underpinning logic within this inference is that complexity is introduced when movers perform in situations where culturally-defined responses are expected of the mover. A corollary is that complexity is possible only when a context allows for different 
movements but demands one. From this perspective, a teacher can remove a situation's potential for complexity either by not allowing different movements and demanding only one (in a drill type activity, for example) or by not demanding any specific movement response at all (as in some forms of creative dance or play, for example).

Accordingly, complex movements should be performed in specific contexts but many authors also add that these contexts must also be dynamic and changing (e.g. Chow et al., 2007). The issue of evolving contexts has been considered in detail by PE scholars interested in complexity theory (Jess et al., 2011; Ovens et al., 2013). These scholars suggest that complex systems such as schools and classrooms, but also individual students, will self-organise based upon the constraints under which they are placed. Scholars drawing on complexity theory emphasize that through selforganization, complex systems produce emergent behaviors, or behaviors that cannot be determined or predicted in advance (Chow and Atencio, 2014). Emergent movement behaviors will in turn interact with the environment and will co-evolve with the environment. From this perspective, complexity is fundamentally related to non-linearity (see Chow, 2013; Chow et al., 2014). Further, since students interact in different ways with their environment, emergent responses will vary. In other words, what is 'complex' for one student may not be 'complex' for another (see Mason, 2008).

The introduction of terms such as 'dynamic' and 'changing' is very often accompanied by complexity when being associated with games and sports contexts (Drost and Todorovich, 2013; Overdorf and Coker, 2013). Indeed, most examples of complex ways of moving given in the literature refer to games and sport. In many cases, references to decision-making and tactical understanding are also made (Avery and Rettig, 2015; Chow et al., 2007). The idea that learning fundamental skills will prepare individuals for complex movements has prompted Okely and Wright (1997) to comment that fundamental motor skills should more accurately be described as fundamental sports skills. Here, it is useful to point out that games/sport and conceptions of fundamental/complex movement (and current understandings of ability in PE for that matter - see Evans and Penney, 2008) can be seen as part of the same discourse. The terms make sense in relation to one another.

Finally, some scholars use 'complex' to signal that reflection or thinking is required. Rukavina and Jeansonne (2009), for example, suggest that students should have opportunities to apply complex concepts when moving. Chow and colleagues propose that 'learning would be optimised if students were engaged in complex and meaningful problem-based activities' (Chow et al., 2007: 252). These claims are part of a wider logic about student-centeredness and the possibilities students have for influencing their learning. In this logic, movement done in environments which encourage students to 'think for themselves,' is seen as both positive and complex.

In conclusion, complex movements can, if all mutually supporting inferences are accounted for, be understood as mature ways of moving that are grounded in the specific practices of games and sport and that involve reflection or thinking. While not all scholars make use of all these aspects, it is possible to employ all of these aspects in a complementary manner because they can 'work' together within one discourse. The aspects do not, in other words, contradict one another's logic. This is perhaps why some scholars have claimed that developing alternative conceptions of movement may involve developing quite different conceptions of PE and moving in PE (Nyberg and Larsson, 2014; Whitehead, 2001). At this point, however, we are interested in the way that complex movement makes sense within the Swedish curriculum. In the next section, we outline a methodological approach for investigating this issue. 


\section{Methodology}

Following Englund and Quennerstedt (2008), we frame our study within a Swedish curriculum theory tradition. Within this line of research, curriculum documents are regarded as 'authoritative educational policy documents' that are analyzed as on-going struggles over the content of education and as 'interpretable political compromises' (Englund and Quennerstedt, 2008: 714). In these documents, it is important to recognise what these authors call performative concepts with symbolic value and the rhetorical use of these concepts, the so called 'essentially contested concepts' (Englund and Quennerstedt, 2008: 715). Within curriculum theory, discourse analysis is a well-used analytical tool to establish possible understandings and alternative meanings of different texts (see, for example, Luke, 1995; Popkewitz and Brennan, 1997). Commonly used in research about public education and opinion forming, discourse analysis is today however often conducted under other labels (Howarth, 2000). Within the field of PE, Rossi et al. (2009) have used discourse analysis to examine the language used in Australian syllabuses. Their examination revealed the neo-liberal logic that pervaded the texts, even when the documents ostensibly advocated socially just principles. In another study, Svendsen and Svendsen (2016) used discourse analysis to show how competitive sport discourses influence PE teacher education. In this case, the scholars claimed that traditional sports logic was preserved in the language of the curriculum. In line with these investigations, our research will uncover assumptions that would otherwise remain implicit and undiscussed, and will add to the body of literature focusing on curriculum production in PE.

\section{Data material selection}

Curriculum documents that are: related to the national curriculum (LGR11); published by the SNAE; and can be retrieved from the SNAE homepage, have been used as data in this investigation. These syllabus texts, support materials, and instructive film clips can be seen as 'authoritative documents' (Englund and Quennerstedt, 2008) which teachers in different ways relate to when they are teaching, assessing and grading students. This set of texts would be an obvious and expected source of information for teachers in the Swedish school system.

After contacting the SNAE, the following texts were located on the SNAE home-page and used as data in this investigation:

- The curriculum and the syllabus in PE for primary school - LGR 11 ('the curriculum'), the main document primarily investigated.

- The commentaries to the course plan in PE ('the commentaries') - supports the teachers by providing a broader and deeper explanation for the reasons behind the formulations in the curriculum based on science.

- The basis for discussion in PE ('the discussion base') - material developed for local subject meetings to help educators understand and implement the curriculum.

- The film about PE ('the PE film') - describes the nature of the subject in general terms and pinpoints what is core and what is new in the curriculum.

- The written assessment support - a written part ('the written assessment support') -intends to give the teacher help in assessing the students together with the film below.

- The film assessment support - a visual part ('the film assessment support') - visualises and supports the written assessment support part with matching examples. 


\section{Discourse theory as a base for discourse analysis}

The discourse analytic approach used in this paper is based on the general idea that 'language is structured according to different patterns that people's utterances follow when they take part in different domains of social life...' (Jørgensen and Phillips, 2002: 1). Accordingly, identifying how a discourse is built up enables us to engage with the objects we encounter, in this case complex movement.

Discourse theory assumes that objects, actions and events involve meaning. Meaning is a product of historically specific systems of rules (Howarth, 2000). Analysis involves trying to provide interpretations of such systems. Structuralists have had a major influence on the development of discourse theory, regarding meaning as a product of the relations between different elements in a system of signs. Jørgensen and Phillips (2002) for example, draw on Saussure, claiming that the meanings of individual signs gain their specific value from their place within other signs.

Social phenomena such as written or enacted texts are never finished or complete in discourse theory and meaning can never be fixed once and for all (Jørgensen and Phillips, 2002). Rather textual phenomena are interpreted on each 'reading' and can always be re-read with a different meaning, even by the same person. Such phenomena are also indexical as they depend on and change with context (Taylor, 2013). This indexicality leads, according to Jørgensen and Phillips (2002), to constant social struggles about definitions of meanings. Discourses that represent the world in one particular way rather than another constitute subjects and objects in certain ways. This creates boundaries between what can be considered true and false and makes certain types of action relevant and others inappropriate and possibly even unthinkable. It is in this sense that discourse is constitutive of the social. Discursive practices are thus in a dialectical relationship with other social practices, and in this sense discourse is socially embedded (Jørgensen and Phillips, 2002). In this paper, we work from the assumption that curricular texts have their roots in the ongoing discourses of PE, sports and health and that the assemblage of these discourses can be identified and traced (for an overview see Penney, 2006).

\section{Discourse analysis - a method of interpreting text}

According to Howarth (2000), discourse analysis is a method that needs to be built up from the purpose of the research. It is necessary to consider discourse analytic traditions but in conducting discourse analysis, some elements can also be put together in new ways. Since discourse analysis is concerned with interpreting and understanding socially produced meanings, the major goals are to delineate the historically specific rules that structure the production of meanings in historical contexts and to: ' . . unmask and delineate taken-for-granted, common-sense understandings, transforming them into potential objects for discussion and criticism' (Jørgensen and Phillips, 2002: 178).

In our paper, we draw specifically on two of Fairclough's (1992) concepts for analyzing these structures - intertextuality and interdiscursivity. Intertextuality concerns how policy texts draw on existing discourses to create new texts. Interdiscursivity is a form of intertextuality where different discourses are understood as: '.... articulated together in a communicative event. Through new articulations of discourses, the boundaries change, both within the order of discourse and between different orders of discourse' (Jørgensen and Phillips, 2002: 73). Power relations are here a main factor that determines the access of different actors to different discourses and limits the possibilities for change. Accordingly, it is possible to look at the way in 
which political forces and social actors construct meanings within what Howarth (2000) calls incomplete and undecidable social structures.

In the investigation, we relied on four specific analytical strategies to identify how the discourse of complex movement was built up in the data. First, we used coding (Kuckartz, 2013) as a link between collecting data and developing an explanation of these data. Second, we adopted a strategy that Jørgensen and Phillips (2002) refer to as substitution. Substitution involved attempting to exchange words with alternatives to see if they (still) made sense. Exchanging 'complex' with 'advanced' for example, made little difference in some of the texts. Third, based on the structuralist idea that a statement gains its meaning by being different from something, we compared the different official documents and examined them in relation to the literature discussed earlier in the paper in terms of intertextuality and interdiscursivity. Finally, we used Culler's (1992) idea of 'understanding and overstanding' to examine the texts. Culler proposes that understanding involves:

... asking the questions and finding the answers that the text insists on. 'Once upon a time there were three little pigs' demands that we ask 'So what happened?' and not 'Why three?' or 'What is the concrete historical context?'. (1992: 114)

Understanding therefore involves analyzing the empirical material on the basis of its own intertextual premises. In order to identify the meaning-bearing units, we ask questions about which language and actions appear in the documents. Overstanding, in contrast, involves asking questions that differ from the obvious. Culler describes overstanding as a reading that 'consists of pursuing questions that the text does not pose to its model reader' (Culler, 1992: 114). In our study, the content offered is placed in relation to the four mutually supporting inferences of complex movement, so that the empirical material can be seen from a different perspective. In this way, the analysis can be deepened and issues that are not immediately obvious can be highlighted. Accordingly, discourse analysis is relatively open-ended and circular.

Practically, analysis of the documents took place in Swedish. Analysis was conducted primarily by the first author with theoretically interesting issues or questions being discussed and debated by all three authors. The four mutually supporting inferences identified in the PE literature were initially used as codes to organise the data. However, coding was not entirely selective and interpretive license was used to identify new codes in an open manner (see Kuckartz, 2013). During coding, recurring features such as particular phrases, terms and figures of speech were identified. This part of the work involved viewing and reviewing the texts as patterns appeared (Quennerstedt, 2008; Wetherell et al., 2001). Once coding was complete, similar codes were collected into categories which were taken as independent classifications of codes that might appear different but intertextually referred to similar phenomena. These categories structure the results section below. When the analysis was complete, results were translated into English by the first author and checked by the second author.

\section{Results}

The initial search in the selected data for an explicitly formulated definition of complex movement yielded little, even though the assessment support material refers readers to the commentaries, suggesting that the commentaries can provide: ' ... a guide to how certain concepts, for example ... complex movement should be interpreted' (the written assessment). We are thus going to 
focus on how the discourse regarding complex movement is assembled, and by doing so, provide insights into the meaning(s) of complex movement within the context of PE policy in Sweden.

\section{Complex movement as advanced movement with a wide meaning}

The results show that the discourse of complex movement as a connotation for advanced (Delaš et al., 2008; Rukavina and Jeansonne, 2009) is a common notion in the curriculum documents. The commentaries frame complex movement as the opposite of simple and fundamental movements, suggesting that engaging in complex movements should lead to all-round movement abilities as opposed to specialised or in-depth movement abilities (the commentaries). In the documents, sports belong on the complex movement 'side' as opposed to simple movement games: 'The progression is such that, the older the students get, the more complex forms of combined movements can be included in the teaching' (the commentaries). Furthermore, 'The progression goes from the motor fundamentals to more complex movements, from simple movement games to more complex games, sports and other physical activities' (the commentaries).

Complex movement is not mentioned in the syllabus for years one to six, but is highlighted for years seven to nine. Movements required in the earlier years could therefore be seen within the discourse as 'non-complex.' This view would be in line with the literature stating that complexity is reserved for older children while fundamental movement is appropriate in primary schools (Delaš et al., 2008; Rukavina and Jeansonne, 2009). This would mean, however, that 'running, jumping and climbing and combinations of these movements using equipment, games and dance and movement to music, both indoor and outdoor' (the commentaries) should be regarded as noncomplex since they take place at primary school. In the commentaries for years seven to nine, 'high jump using certain techniques' is cited as an example of a complex movement.

For the later years, still non-complex, sports are added '[participation] with different degrees of confidence and precision, even in group situations' (the commentaries). Dance and movement to music are however excluded: 'There are currently two parts of the knowledge requirements that deal with movement, one that deals with partaking in play, games and sports that contain different degrees of complex movement, and one part that deals with the ability to move to music in dances and in work out programmes' (the written assessment). This text suggests that dance, at least as it is constructed within the complex movement discourse, is a non-complex activity.

The grading criteria for the lowest passing grade in the Swedish system - an 'E', years seven to nine - state that: 'Pupils can participate in games and sports involving complex movements in different settings and vary and adapt their movements to some extent to activities and context' (the curriculum). The assessment support material represents these requirements with an obstacle course where the instructions are as follows: 'You are to move in a movement course with stations that demand complex movements. The course gives you opportunities to choose the difficulty level' (the written assessment). The obstacle course shown in the film assessment support consists of elements where students must for example, walk backwards on a thin bar elevated one meter above ground (Figure 1), walk along a beam elevated $20 \mathrm{~cm}$ above ground (Figure 2), and jog around cones in a zigzag pattern (Figure 3 ).

This example suggests that all students at this level are to be involved in complex movement in order to pass. At the same time the ambition is that all students should be given opportunities to take part in different movement activities according to their individual abilities. By offering a wide range of activities such as games, gymnastics, sports, dance and movement to music, this position is strengthened (the commentaries, pp. 6,8). Since all students should be able to participate 


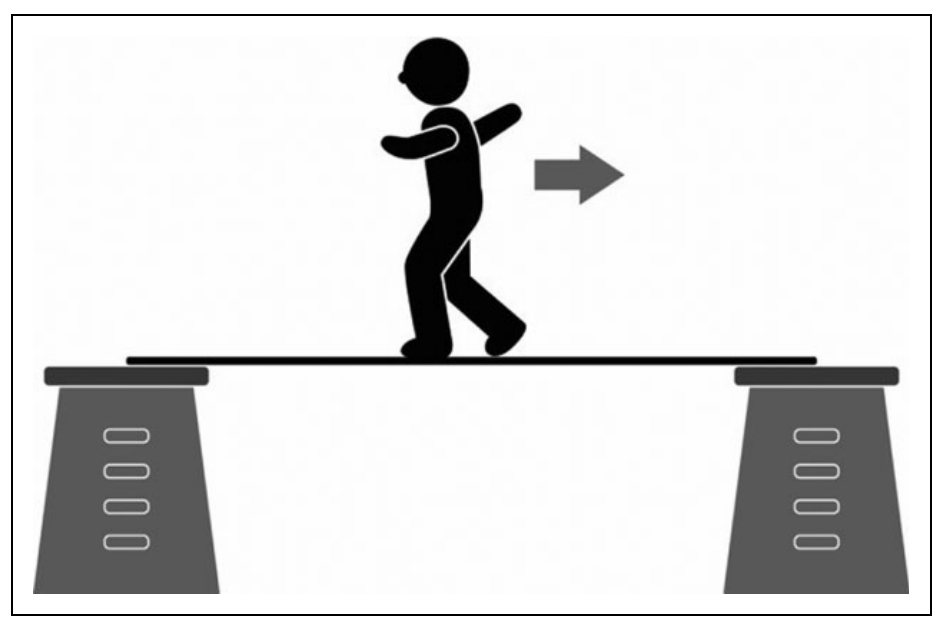

Figure I. Example of complex movement, taken from the film assessment support, showing a student walking backwards on a thin bar elevated I $\mathrm{m}$ above ground.

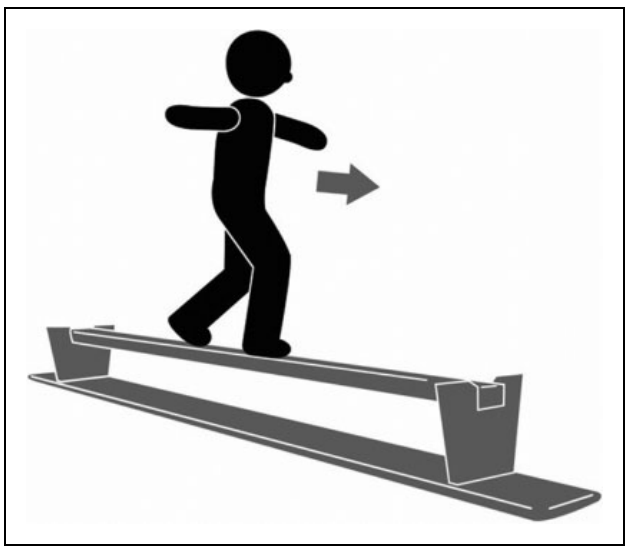

Figure 2. Example of complex movement, taken from the film assessment support, showing a student walking forward on a wide bar elevated $20 \mathrm{~cm}$ above ground.

according to their ability and since all students should take part in complex movements, complex movement must be either quite simple or the range of what it means quite broad.

\section{Complex movement as depending on context in sports for older pupils}

There are a number of references in the data to complex movement in changing, dynamic contexts (see Chow et al., 2007; Drost and Todorovich, 2013; Overdorf and Coker, 2013). These appear, for example, in descriptions of different forms of sport where decision-making is occurring. Nonetheless, there is no consideration of how different games and sport might vary according to how changing and dynamic they are. Nor is there any specific explanation of why sports and games that are played up till the sixth grade are described as non-complex but those played in seventh grade and beyond are 


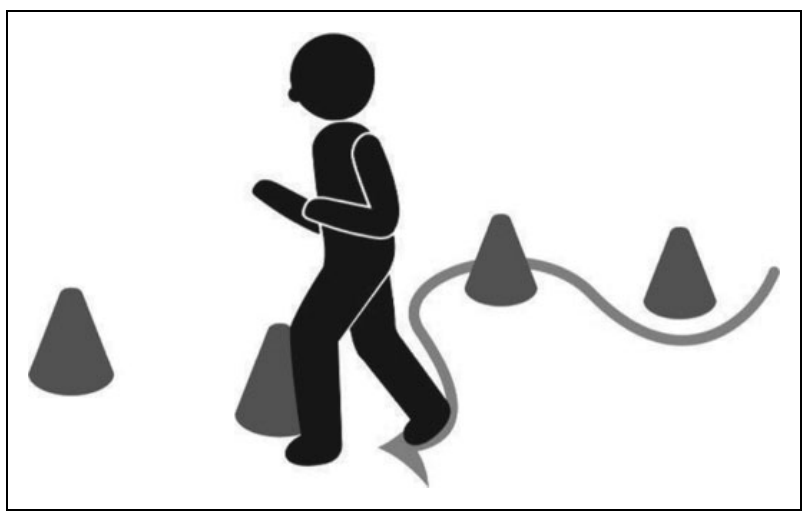

Figure 3. Example of complex movement, taken from the film assessment support, showing a student jogging forward around cones in a zigzag pattern.

complex. The suggestion is that somewhere between the sixth and seventh grades, something should happen with sports that in accordance with the documents will make them complex.

\section{Complex movement as depending on knowledge but without a common view about knowledge}

The curricular documents stress that it is the use of certain kinds of knowledge and understanding together with moving (Rukavina and Jeansonne, 2009) that makes movement complex. In the documents, however, the purpose and knowledge content of PE regarding complex movement is not made explicit (the PE film). The commentaries state that complex movement is closely related to knowledge: 'The subject's knowledge assignment is emphasized. With that is meant that the school should not try to make the students more physically active in the first place, but above all give them knowledge of how to best develop bodily ability' (the commentaries). This involves: 'the students' ability to develop joy of movement, coordination, condition, strength, flexibility, mental capacity and motivation' (the commentaries). However, these aspects of PE are then, not explicitly, related to complex movement either individually or in combinations and indicate that by performing complex movement, a student will develop joy of movement in the best way. In line with the commentaries, the assessment support states that: ' . . movement deals with developing the ability to move in different ways and in different physical contexts ... learning aims to enable participation in movement' (the written assessment). Finally, the commentaries state that complex movement is not knowledge to receive but knowledge as a process (the commentaries).

\section{Discussion}

The specific aim of this investigation was to identify how the discourse regarding complex movement is assembled, and by doing so, provide insights into the meaning(s) of complex movement within the context of PE policy in Sweden. In the overview of the field we identified four mutually supporting inferences regarding complex movements: (i) complex as advanced; (ii) complex as context-dependent; (iii) complex as dynamic and changing; and (iv) complex as demanding reflective processing. The analysis shows that it is possible to identify and trace these 
inferences in order to understand the performative assumptions of the concept in terms of its consequences (cf. Englund and Quennerstedt, 2008).

We have shown that the documents give complex movement multiple and at times contradictory meanings. In general, the documents formulate complex movement as advanced movements that require consideration of context. At the same time, students should develop a broad range of movement abilities. Terms such as 'broad' and 'all-round' do not necessarily rule out the development of specialised movement skills, but they do work to create a hierarchy that places fundamental at the bottom and complex at the top. However, the description of some activities as complex and others as implicitly non-complex raises questions. What is it about high jump that is complex and swimming that is non-complex? How could activities such as swimming be adapted in order to make them complex? Is it possible for games and sports to be conducted in non-complex ways?

In addition to these questions, Larsson and Quennerstedt (2012) acknowledge an interactional dimension of meaning-making and ask for whom and in relation to what movement is complex. In line with complexity theory (Mason, 2008), we can expect students to have different movement histories and to experience movement contexts in PE differently. It may be useful though to consider how teachers make sense of complex movement. For example, we might examine how teachers' histories and cultures predispose them to understand complex movement in some ways but not others. In the absence of clear demarcations in policy, we might also investigate how teachers distinguish between complex and non-complex. We would suggest that this is a particularly relevant line of research in educational environments where PE teachers are responsible for transforming policy into assessment and grading practices (Svennberg, 2017; Tolgfors and Öhman, 2016).

The curricular documents examined here stress the importance of knowledge and understanding together with movement, suggesting that this combination results in complexity. This is not a new idea and others have claimed that movement needs to be accompanied by reflection if it is to be complex (Rukavina and Jeansonne, 2009). At the same time, this position raises epistemological issues concerning what it means to know in PE (for example, Fernandez-Balboa et al., 1996; Kirk, 2010). Is it possible, for instance, to perform a movement without being able to articulate how one did it? For Ekberg (2014) knowledge in PE is in any case a performative concept associated with uncertainty. The curricular material presented in this investigation, despite having the aim of clarifying expectations and supporting teachers, appears to do little to dispel the uncertainty.

Contradictions in the documents can intertextually as well as interdiscursively be described as: (i) complex movement is simple and for everyone but also quite specific where particular ways of moving are privileged; (ii) complex movement is not to be considered as contextual yet it is mainly in the context of sport or assessment that complex movement can be found; and (iii) complex movement is about knowledge; however, it is not clear if knowledge needs to be articulated in words in order to be authentic. Further, some movement activities, while appearing similar, are framed as complex while others are framed as non-complex.

\section{Concluding remarks}

It is difficult to say exactly why 'complex movement' now appears in the Swedish curricular description for PE. The term 'complex' can be found in descriptions of other school subjects such as mathematics and science in Swedish educational policy. It may be that it has been included for philological alignment, borrowed for example from the common European framework for language (CEFR) (the commentaries). What has become clear is that the term has caused PE teachers 
to ask some critical questions about an element of their practices that has long remained unquestioned (Redelius et al., 2015; Svennberg et al., 2014).

The discursive analysis conducted here suggests that policy provides no simple answers for teachers. A definition for complex movement must be assembled from extracts found in the Swedish curricular documents. Only by putting complex movement in relation to other concepts and 'reading between the lines' can teachers make sense of the term. It is difficult to see exactly how complex movement in PE differs from advanced or good quality movement, for example, or how the use of the term complex might contribute to the realization, assessment and grading of PE practices. Indeed, transformation to practice is an area that we believe deserves further attention.

We would like to add a final reflection. Like scholars who have examined PE policy before us (Rossi et al., 2009; Svendsen and Svendsen, 2016), we would suggest that such curricular analyses reveal complexity and contradictions. Rather than 'clear up a messy issue,' they have the potential to inform educators as they interpret and transform policy. In this case, we have investigated an aspect that is central to the work of physical educators and shown how the texts might be read. We acknowledge, however, that PE policy continues to change and that when the curriculum is revised, new readings will be invited. It is for this reason that we propose that curriculum research will continue to be a valuable part of PE scholarship.

\section{Declaration of Conflicting Interests}

The authors declared no potential conflicts of interest with respect to the research, authorship, and/or publication of this article.

\section{Funding}

The authors received no financial support for the research, authorship, and/or publication of this article.

\section{Note}

1. The Swedish national curriculum is mandatory for all schools in Sweden except for Sámi schools (a type of school in Sweden that runs parallel to the standard primary school system), some schools that have been created to educate children with special needs, and schools that follow international curricula. The main changes for the 2011 curriculum revolved around centralization and a desire for clearer goals. For PE, the grading system also was changed from four levels to seven.

\section{References}

Avery M and Rettig B (2015) Teaching the middle school grade-level outcomes with standards-based instruction. Journal of Physical Education, Recreation and Dance 86(7): 17-22.

Barker DM, Bergentoft H and Nyberg G (2017) What would physical educators know about movement education? A review of literature, 2006-2016. Quest 69(4): 419-435.

Boyce BA, Coker C and Bunker LK (2006) Implications for variability of practice from pedagogy and motor learning perspectives: Finding a common ground. Quest 58(3): 330-343.

Brown T and Payne P (2009) Conceptualizing the phenomenology of movement in physical education: Implications for pedagogical inquiry and development. Quest 61(4): 418-441.

Brown T and Penney D (2013) Learning 'in', 'through' and 'about' movement in senior physical education? The new Victorian Certificate of Education Physical Education. European Physical Education Review 19(1): 39-61.

Chow JY (2013) Nonlinear learning underpinning pedagogy: Evidence, challenges, and implications. Quest 65(4): 469-484. 
Chow JY and Atencio M (2014) Complex and nonlinear pedagogy and the implications for physical education. Sport, Education and Society 19(8): 1034-1054.

Chow JY, Davids KW, Button C, et al. (2007) The role of nonlinear pedagogy in PE. Review of Educational Research 77(3): 251-278.

Culler J (1992) In defence of overinterpretation. In: Collini S (ed.) Interpretation and Overinterpretation. Cambridge, UK: Cambridge University Press, pp.109-123.

Delaš S, Miletić A and Miletić Đ (2008) The influence of motor factors on performing fundamental movement skills: The differences between boys and girls. Facta Universitatis, Series: Physical Education and Sport 6(1): 31-39.

Drost DK and Todorovich JR (2013) Enhancing cognitive understanding to improve fundamental movement skills. Journal of Physical Education, Recreation and Dance 84(4): 54-59.

Ekberg J-E (2014) What knowledge appears as valid in the subject of Physical Education and Health? A study of the subject on three levels in year 9 in Sweden. Physical Education and Sport Pedagogy 21(3): 249-267.

Englund T and Quennerstedt A (2008) Linking curriculum theory and linguistics: The performative use of 'equivalence' as an educational policy concept. Journal of Curriculum Studies 40(6): 713-724.

Evans J and Penney D (2008) Levels on the playing field: The social construction of physical 'ability' in the PE curriculum. Physical Education and Sport Pedagogy 13(1): 31-47.

Fairclough N (1992) Discourse and Social Change. Cambridge, UK: Polity Press.

Fernandez-Balboa JM, Barrett K, Solomon M, et al. (1996) Perspectives on content knowledge in physical education. Journal of Physical Education, Recreation and Dance 67(9): 54-57.

Ha AS, Wong AC, Sum RK, et al. (2008) Understanding teachers' will and capacity to accomplish physical education curriculum reform: The implications for teacher development. Sport, Education and Society 13(1): 77-95.

Howarth D (2000) Discourse. Buckingham, UK: Open University Press.

Jess M, Atencio M and Thorburn M (2011) Complexity theory: Supporting curriculum and pedagogy developments in Scottish physical education. Sport, Education and Society 16(2): 179-199.

Jørgensen M and Phillips LJ (2002) Discourse Analysis as Theory and Method. London, UK: SAGE Publications.

Kentel J and Dobson A (2007) Beyond myopic visions of education: Revisiting movement literacy. Physical Education and Sport Pedagogy 12(2): 145-163.

Kirk D (2010) Physical Education Futures. London, UK: Routledge.

Kuckartz U (2013) Qualitative Text Analysis: A guide to Methods, Practice and Using Software. London, UK: SAGE Publications.

Larsson H and Quennerstedt M (2012) Understanding movement: A sociocultural approach to exploring moving humans. Quest 64(4): 283-298.

Larsson H and Nyberg G (2017) 'It doesn't matter how they move really, as long as they move.' 'Physical education teachers on developing their students' movement capabilities. Physical Education and Sport Pedagogy 22(2): 137-149.

Light R and Wallian N (2008) A constructivist-informed approach to teaching swimming. Quest: 60(3): $387-404$.

Luke A (1995) Text and discourse in education: An introduction to critical discourse analysis. Review of Research in Education 21(1): 3-48.

Lundvall S and Meckbach J (2008) Mind the gap: Physical education and health and the frame factor theory as a tool for analysing educational settings. Physical Education and Sport Pedagogy 13(4): $345-364$.

Macdonald D (2013) The new Australian health and physical education curriculum: A case of/for gradualism in curriculum reform? Asia-Pacific Journal of Health, Sport and Physical Education 4(2): 95-108.

Mason M (2008) Complexity theory and the philosophy of education. Educational Philosophy and Theory 40(1): 4-18. 
McCuaig L, Quennerstedt M and Macdonald D (2013) A salutogenic, strengths-based approach as a theory to guide HPE curriculum change. Asia-Pacific Journal of Health, Sport and Physical Education 4(2): $109-125$.

Miller J, Vine K and Larkin D (2007) The relationship of process and product performance of the two-handed sidearm strike. Physical Education and Sport Pedagogy 12(1): 61-76.

Nyberg G and Larsson H (2014) Exploring 'what' to learn in PE. Physical Education and Sport Pedagogy 19(2): 123-135.

Okely A and Wright J (1997) The gender bias in fundamental motor skills tests: A new agenda needed. Paper presented at the AARE conference, Brisbane, Australia; 1997. Available at: https:/www.aare.edu.au/data/ publications/1997/okela137.pdf (accessed 20 June 2018).

Ovens A, Hopper T and Butler J (eds) (2013) Complexity Thinking in Physical Education: Reframing Curriculum, Pedagogy, and Research. New York, NY: Routledge.

Overdorf V and Coker C (2013) Efficacy of movement analysis and intervention skills. The Physical Educator 70(2): 195-205.

Peiroó-Velert C, Molina-Alventosa P, Kirk D, et al. (2015) The uses of printed curriculum materials by teachers during instruction and the social construction of pedagogic discourse in physical education. Journal of Teaching in Physical Education 34(1): 18-35.

Penney D (2006) Curriculum construction and change. In: Kirk D, Macdonald D and O'Sullivan M (eds) The Handbook of Physical Education. London, UK: SAGE Publications, pp.565-579.

Penney D (2008) Playing a political game and playing for position: Policy and curriculum development in health and physical education. European Physical Education Review 14(1): 33-49.

Penney D, Brooker R, Hay P, et al. (2009) Curriculum, pedagogy and assessment: Three message systems of schooling and dimensions of quality physical education. Sport, Education and Society 14(4): $421-442$.

Popkewitz TS and Brennan M (1997) Restructuring of social and political theory in education: Foucault and a social epistemology of school practices. Educational Theory 47(3): 287-313.

Quennerstedt M (2008) Studying the institutional dimension of meaning making: A way to analyze subject content in physical education. Journal of Teaching in Physical Education 27(3): 434-444.

Redelius K, Quennerstedt M and Öhman M (2015) Communicating aims and learning goals in physical education: Part of a subject for learning? Sport, Education and Society 20(5): 641-655.

Rossi T, Tinning R, McCuaig L, et al. (2009) With the best of intentions: A critical discourse analysis of physical education curriculum materials. Journal of Teaching in Physical Education 28(1): 75-89.

Rukavina PB and Jeansonne JJ (2009) Integrating motor-learning concepts into PE. Journal of Physical Education, Recreation and Dance 80(9): 23-65.

Schenker K (2012) Skolverkets bedömningsstöd - koncepten matchar inte principen [The Agency's assessment support concept does not match the principle]. [In Swedish.] Available at: https://idrottsforum.org/ forumbloggen/skolverkets-bedomningsstod-koncepten-matchar-inte-principen/ (accessed 2 October 2018).

Seger I (2014) Betygsättningsprocess i ämnet idrott och hälsa: en studie om betygsättningsdilemman på högstadiet [Grading process in the subject of sport and health: a study on the high school graduation film]. Licentiate Dissertation, Örebro University, Sweden. [In Swedish.] Available at: https://www.divaportal.org/smash/get/diva2:757718/FULLTEXT01.pdf (accessed 2 October 2018).

Skolverket (2011) LGR11. Västerås, Sweden: Edita. [In Swedish.]

Stodden DF, Goodway JD, Langendorfer SJ, et al. (2008) A developmental perspective on the role of motor skill competence in physical activity: An emergent relationship. Quest 60(2): 290-306.

Svendsen AM and Svendsen JT (2016) Teacher or coach? How logics from the field of sports contribute to the construction of knowledge in physical education teacher education pedagogical discourse through educational texts. Sport, Education and Society 21(5): 796-810.

Svennberg L (2017) Swedish PE teachers' understandings of legitimate movement in a criterion-referenced grading system. Physical Education and Sport Pedagogy 22(3): 257-269. 
Svennberg L, Meckbach J and Redelius K (2014) Exploring PE teachers' 'gut feelings': An attempt to verbalise and discuss teachers' internalised grading criteria. European Physical Education Review 20(2): 199-214.

Taylor S (2013) What is Discourse Analysis? London, UK: Bloomsbury.

Tholin J (2006) Att kunna klara sig i ökänd natur: en studie av betyg och betygskriterier-historiska betingelser och implementering av ett nytt system [Being able to cope with infamous nature: a study of grades and grading criteria - historical conditions and implementation of a new system]. Doctoral Dissertation, Högskolan i Borås. [In Swedish.] Available at: http://www.diva-portal.org/smash/record.jsf?pid= diva2\%3A876774\&dswid=4300 (accessed 2 October 2018).

Thorburn M and Collins D (2006) The effects of an integrated curriculum model on student learning and attainment. European Physical Education Review 12(1): 31-50.

Tolgfors B and Öhman M (2016) The implications of assessment for learning in physical education and health. European Physical Education Review 22(2): 150-166.

Wetherell M, Taylor S and Yates SJ (2001) Discourse as Data: A Guide for Analysis. London, UK: SAGE Publications, in association with the Open University.

Whitehead M (2001) The concept of physical literacy. European Journal of Physical Education 6(2): 27-138.

Web links referred to by the Swedish National Agency for Education: Swedish National Agency for Education. The curriculum and the course plan in physical education for primary school: www.skolverket.se/ laroplaner-amnen-och-kurser/grundskoleutbildning/grundskola/idrott-och-halsa (accessed 20 June 2018).

Swedish National Agency for Education. Commentaries to the course plan in physical education: https:// www.skolverket.se/publikationer?id=2589 (accessed 20 June 2018).

Swedish National Agency for Education. Basis for discussion in physical education: https://www.skolverket. se/publikationer?id=2536 (accessed 20 June 2018).

Swedish National Agency for Education. The film about physical education: https://www.youtube.com/

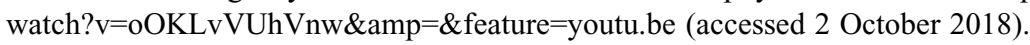

Swedish National Agency for Education. The publication database: https://www.skolverket.se/om-skolver ket/publikationer (accessed 20 June 2018).

Swedish National Agency for Education. The assessment support: https://bp.skolverket.se/web/bs_gr_ grgridh01_7-9/information (accessed 20 June 2018).

\section{Author biographies}

Lucas Janemalm is a PhD Candidate at Örebro University, Sweden and is currently employed at the International High School of the Gothenburg Region, Sweden.

Mikael Quennerstedt is Professor in PE and Health at Örebro University, Sweden.

Dean Barker is Associate Professor in PE and is currently employed at the University of Gothenburg and The Swedish School of Sport and Health Sciences (GIH), Sweden. 